\title{
Surfaces
}

\section{Confucius at the Center of a Humanistic Discourse or "Cheng Hsuan Awakened from a Dream"}

\section{Ching-hsien Wang}

Volume 5, 1995

DEUXIÈME CONGRÈS INTERNATIONAL SUR LE DISCOURS

HUMANISTE (1995)

SECOND INTERNATIONAL CONFERENCE ON HUMANISTIC

DISCOURSE (1995)

URI : https://id.erudit.org/iderudit/1064996ar

DOI : https://doi.org/10.7202/1064996ar

Aller au sommaire du numéro

Éditeur(s)

Les Presses de l’Université de Montréal

ISSN

1188-2492 (imprimé)

1200-5320 (numérique)

Découvrir la revue

Citer cet article

Wang, C.-h. (1995). Confucius at the Center of a Humanistic Discourse or "Cheng Hsuan Awakened from a Dream". Surfaces, 5. https://doi.org/10.7202/1064996ar
Résumé de l'article

Ce texte est un poème traduit du Chinois en Anglais, par son auteur. Les annotations donnent le contexte historique auquel le poème se réfère.
Copyright (c) Ching-hsien Wang, 1995

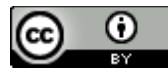

Ce document est protégé par la loi sur le droit d'auteur. L'utilisation des services d’Érudit (y compris la reproduction) est assujettie à sa politique d'utilisation que vous pouvez consulter en ligne.

https://apropos.erudit.org/fr/usagers/politique-dutilisation/ 


\section{Confucius at the Center of a Humanistic Discourse}

\section{or "Cheng Hsuan Awakened from a Dream"모}

Ching-hsien Wang

University of Washington

Department of Asian Languages \& Literature

Seattle, WA

98195

Surfaces Vol.V.204 (v.1.0A - 10/11/1995)

Copyright for texts published in SURFACES remains the property of authors. However, any further publication should be accompanied by an acknowledgement of SURFACES as the place of initial publication.

ISSN: $1188-2492$

\section{ABSTRACT}

This text is a poem translated by the author from Chinese into English. The annotations furnish information about the historical context to which the poem refers.

\section{RÉSUMÉ}

Ce texte est un poème traduit du Chinois en Anglais, par son auteur. Les annotations donnent le contexte historique auquel le poème se réfère.

\section{The 5th year of Chien-an, keng-ch'en, Emperor Hsien of Han (A.D. 200) 1}

Spring night. After some wine...

The Sage never died: "Arise! It is the dragon this year, It will be the snake next." Has the timber beam decayed?

I push open the window and see a marvelous tree blossom in the yard As pebbles glisten dimly around, under a crescent moon.

Further beyond the wall there is the myriad acreage of darkness:

Yuan Shao and Ts'ao Ts'ao grapple at Commissionerford.2 Arise, 
Arms grumble and whine on the edges of the misty river.

When I was young I worked as a petty officer, back at home I arbitrated litigations and collected taxes-How could I, Cheng K'angch'eng

Of North Sea, stay on a job like that forever? I realized that

King Wen did settle quarrels in antiquity, but the contenders, before

They spoke up, would become reconciled in his presence. $\underline{3}$ To process a litigation is

To end all litigations but, alas, it generates endlessly more...

The Sage has been long dead. Whenever I recall the song

About how one ploughs on and off and draws water from his well to drink, et cetera,

I'm ashamed to be a scrupulous, fastidious public functionary.

Besides, when Mencius cited the well system to Duke Wen of T'eng he said:

"As for

Benevolent embellishments they're up to your prince and you." $\underline{4}$ And yet

Wang Mang tried it in the New era and failed, a greatly erroneous thing! $\underline{5}$

There are still some perfect measures hidden in certain books, perhaps,

If only one can detect them, perhaps in the nine-chapter Reckoning

Implements. $\underline{6}$

Ma Jung of Gale summoned me upstairs and asked for /pp. 6-7/

My Opinion, in the slanting shine of the analytical, interrogating evening sun,

About control, distribution, surplus, shortage. Roughly so was my study in the West. 7

As I was taking leave from him, the master sighed, saying:

"Once he returns to the East my tao surely extends in that direction."

With me, Gale means

but the Mao tradition of Poetry. $\underline{8}$

He reshaped an intellectual apparatus, defined my ambition:

I dropped Han Ying's comparative hermeneutics, the exegesis internal and external,

And turned to Mao's text in 29 parts, supplemented with random theories Maintained by the Lu and Ch'i schools. In terms of philology he even could not compare

With me. For River Ch'i has its banks and the swamp, its brink. 9

So, assuming that I might rank along with Tzu-yu and Tzu-hsia

In Confucius' classroom, the Sage, I'm afraid, would say

"Hsüan it is who bears out my lofty thoughts!" I'm pretty sure he would.

What about such peers as Yen Hui, Tsai Yü, Jan Yu, then?

How would I look in respect of their expertise. I, Cheng K'ang-ch'eng, I have once declined Ho Chin's voucher and, again, refused Yuan Wei's recommendation,

In order to farm in East Grass, rather, and to attend to scholarship-

Yen Hui's was a chaotic time, and world, and his reticent virtue was so, Not much different from mine, or at least I am comparable with Min Tzuch'ien. As for

Political science I did expound the Reckoning Implements to Ma Jung, As I mentioned earlier, and I assume that I am not inferior to Tuan-mu Szu. $\underline{10}$ 
Once, at the age of seventy, I appeared in the Grand Marshal's mansion as a Confucian,

Drank a pitcher of wine, and derided Ying Shao of South Dame, who was erudite. 11

"The Confucian curriculum is comprised of four subjects."12 I sneered

And said to him: "Yen Hui and Tuan-mu Szu never sought fame in government office."

So I rejected taking any official bureaucrat as student. That is evidence of My oratory, which is sufficiently eloquent indeed. I,

Cheng K'ang-ch'eng, have advanced too far in years.

What a balmy spring night it is tonight! Ying Shao is not entirely wrong"The Ministry of Spring is testified by Wood," he notes. See

How things grow luxuriantly in multitude now!

There is the marvelous tree blossoming upright in the breezy yard,

Lilies sleep soundly in the pond awaiting the dawn to break,

And China tosses about in my classical scholarship. "Arise."

Confucius knocked my foot gently with a cane, and said:

"Dragon it is this year, and snake it will be next."

Worthy men all deplore it when the year turns to the dragon and snake.

Verifying the maxim with an oracle,

I know I shall die.

\section{NOTES}

A Cheng Hsuan (127-200, styled K'ang-ch'eng, a preeminent exegete of the Confucian classics, was from Kao-mi in the Commandery of Pei-hai (North Sea). A biography is found in The History of the Later Han Dynasty 35.

1 Emperor Hsien (r. 189-220) was the last monarch on the throne of the Later Han Dynasty, which was followed by the Three Kingdoms period.

2 Yuan Shao (?-202) and Ts'ao Ts'ao (155-220), both military contenders for hegemony during Emperor Hsien's reign. The latter had a son, Ts'ao P'i, who brought the Han Dynasty to an end and founded the Wei Dynasty (220-265); hence he was known posthumously as Emperor Wu of Wei.

Commissionerford, Kuan-tu, situated between modern Cheng-chou and K'aifeng, is approximately 20 kilometers south of the Yellow River today, but in A.D. 200 it was approximately 60 kilometers south of the River, which changed its course frequently in history.

$\underline{3}$ King Wen of the Chou Dynasty (ca. 1111-250 B.C.) was known as the Count of the West in the earlier stage of his charismatic life. Once the people of Yu and Jui had an irresolvable dispute over property, so they went to seek justice before him. As soon as they entered his domain they saw that there even the farmers were polite and all respected the elders. The people of Yu and Jui grew ashamed and said to each other: "What we fight for is what the Chou resent. For what purpose are we going to him? We would only find ourselves disgraced for our greed." Thereupon, turning back they took leave of each other with courtesy. For detail, see The Records of the Grand Historian 4. 
$\underline{4}$ Mencius III. A. 3.

$\underline{5}$ Wang Mang usurped the throne of the Former Han Dynasty and founded the Hsin (New) Dynasty (9-23).

6 Chiu-chang suan-shu, attributed to the Duke of Chou (12th century B.C.), comprises nine chapters about computation and public financial management. It was most likely written (by an anonymous author) in the 2nd century B.C.

7 Ma Jung (79-166), styled Chi-chang, was a poet and scholar from Mao-ling in the Commandery of Fu-feng (Gale).

8 Shih Ching, or The Classic of Poetry, is one of the six Confucian classics. In addition to the Mao, there were the Han, Lu and Ch'i schools competing for authority in interpreting the ancient text.

9 Poetry 58/6.

10 Tzu-yu, Tzu-hsia, Yen Hui, Tsai Yü, Jan Yu, Min Tzu-ch'ien, Tuan-mu Szu (Tzu-kung) were among the most distinguished of Confucius' disciples. See The Analects.

11 Ying Shao, styled Chung-yuan, a broadly knowledgeable scholar from Nan-tun in the Commandery of Ju-nan (South Dame), served in Marshal Yuan Shao's camp.

$\underline{12}$ Virtue, oratory, government, literary studies. 